\title{
ERO YHTEISKUNNALLISENA KYSYMYKSENÄ
}

\section{Pääkirjoitus}

\section{o}

Perhetutkimus on monitieteinen tutkimusalue, jossa perheitä, perhe-elämää ja sen muutoksia tarkastellaan eri näkökulmista, tänä päivänä erityisesti perhesuhteiden ja yksilöllisten kokemusten kautta. Tässä Januksen teemanumerossa keskitytään avo- ja avioerojen aiheuttamiin perhesuhteiden muutoksiin hieman toisesta näkökulmasta ja pohditaan eroa laajakantoisena yhteiskunnallisena kysymyksenä. Miten ero ymmärretään ja millaisia vaatimuksia tai velvollisuuksia yhteiskunnan suuntaan se tuo tullessaan? Millaisena ero näyttäytyy suomalaisen sosiaali- ja yhteiskuntapolitiikan tehtäväkentässä ja palvelujärjestelmässä, jossa sosiaalityön mutta myös muiden alojen eroammattilaisilla on merkittävä rooli?

Perhesuhteiden muutokset eivät kosketa vain yksilöitä, vaan ne luovat myös uudistumispaineita yhteiskunta- ja perhepolitiikalle. Avo- ja avioliittojen purkautuminen ja uusien liittojen muodostuminen synnyttävät perhe- ja läheissuhteissa liikettä, jolla on moninaisia yhteiskuntapoliittisia seurauksia esimerkiksi asumiseen, talouteen ja kasvatus- ja elatusvastuisiin.Vaikka eroa pidetään tänä päivänä parisuhteen osapuolten yksityisasiana ja henkilökohtaista elämää koskevana valintana, sen seurauksia pyritään säätelemään yhteiskuntapolitiikan keinoin.

Yhteiskunnallisena kysymyksenä ero kiinnittyy tänä päivänä lapsiin, vanhemman ja lapsen suhteeseen ja "hyvään vanhemmuuteen" eron jälkeen. Keskeisenä pidetään suhteiden jatkumista, vanhempien sopimuksellisuutta lapsen asioista päätettäessä ja riitojen sovittelua ja ratkaisemista. Lasten toimeentulo ja elatus yhden vanhemman perheissä on ollut yhteiskuntapoliittinen kysymys jo yli 100 vuoden ajan ja se on viime vuosina noussut uudelleen esille lapsiperheiden köyhyyttä koskevan tutkimuksen ja yhteiskunnallisen keskustelun ansiosta.

Teemanumeron artikkeleissa painottuvat erot lapsiperheissä, mutta toisin kuin aiemmassa suomalaisessa tutkimuskeskustelussa päähuomio ei ole erossa perheen sisäisenä tai perhedynaamisena kysymyksenä. Tällainen näkökulma on tärkeä, mutta vaatii rinnalleen myös toisen tarkastelukulman. Numerossa tarkastellaan eroon liittyviä kulttuurisia käsityksiä ja niiden historiallista muutosta, perheammattilaisten ja eroasiantuntijoiden näkemyksiä erovanhemmuudesta, eroon liittyviä palvelujärjestelmän käytäntöjä ja erojen käynnistämää taloudellisten resurssien uudelleenjakoa. Pyrimme pääsemään käsiksi siihen, mikä parisuhteen päättymisessä ja eron seurauksissa on yleistä ja yhteiskunnallisesti huomioitavaa yksittäisistä perhe- ja pa- 
risuhdetilanteista riippumatta. Syntyvä ymmärrys auttaa määrittämään, miten eroja suomalaisten perhe-elämään kuuluvana ilmiönä voi tai kannattaa yrittää säädellä,ja kenen näkökulmaa eron vaikutuksiin on tarpeen priorisoida.

Ensimmäisessä artikkelissa Anna-Maija Castrén, Hannele Forsberg ja Aino RitalaKoskinen tarkastelevat, miten käsitys erosta on Suomessa muuttunut harvinaisesta ja kielletystä joksikin, joka on tavanomaista, yleistä ja hyväksyttyä. Ero ymmärretään nykyisin ensisijaisesti aikuisten parisuhdetta koskevaksi ratkaisuksi, jonka seurauksena lasten elämä joudutaan järjestämään uudelleen. Lapsen asioista sopiminen ei aina ole helppoa ja joissain tilanteissa vaaditaan yhteiskunnan välintuloa. Aino Kääriäisen artikkeli käsittelee sosiaalitoimen käräjäoikeudelle laatimia selvityksiä lapsen olosuhteista huoltoriidassa. Kiinnostus kohdistuu siihen, millä tavoin ammattilaiset muodostavat, tuottavat ja sanoittavat lapsen käsityksiä huoltoriidassa. Lapsen kuuleminen on tärkeä osa eroprosessia ja se voi auttaa sekä vanhempia että viranomaisia tekemään lapsen edun mukaisia ratkaisuja sekä huomioimaan paremmin lapsen näkökulman eropalveluissa. Leena Autonen-Vaaraniemi puolestaan tarkastelee erojen parissa työskentelevien perheammattilaisten suhtautumista vanhemmuuteen ja nostaa esille, kuinka eri alojen ammattilaiset pitkälti jakavat ymmärryksen eron jälkeisestä hyvästä vanhemmuudesta. Mari Haapasen ja Mia Hakovirran artikkelissa tutkitaan erojen taloudellisia seurauksia ja sitä, miten vanhemmat jakavat keskenään taloudellista vastuuta lapsista ja miten yhteiskunta on ottanut vastuulleen turvata lapsen toimeentuloa eron jälkeen. Artikkelit sanoittavat kukin omasta rajatusta näkökulmastaan erojen institutionalisoitumisen prosessia suomalaisessa yhteiskunnassa. Tietynlainen ymmärrys erosta muodostuu jaetuksi käsitykseksi, joka vaikuttaa monenlaisessa perheisiin ja perhesuhteisiin liittyvässä yhteiskunnallisessa toiminnassa, kuten palveluissa ja juridisessa sääntelyssä. Parisuhteiden purkautumisen ja lasten eron jälkeisen elämän ympärille kehkeytyy normeja ja arvokeskustelua - siis käsityksiä siitä, mikä on hyvää ja tavoiteltavaa eroon liittyen ja mikä puolestaan huonoa ja vältettävää.

Neljä artikkelia on väistämättä suppea kuvaus erosta laajakantoisena sosiaalisena ja yhteiskunnallisena ilmiönä. Puheenvuorot ja kirja-arviot täydentävät kokonaisuutta, mutta edelleen paljon jää puuttumaan. Yhteiskunnallinen muutos edellyttää tutkimusta eroista erilaisissa perhetilanteissa heteroparien lapsiperheiden ohella, kuten sateenkaariperheissä, monikulttuurisissa perheissä tai uus-, adoptio- ja sijaisperheissä. Näihin kaikkiin liittyy yhdistävien seikkojen lisäksi erityispiirteitä, jotka asettavat vaatimuksia perheammattilaisille ja yhteiskunnan palvelujärjestelmälle. Eräs ajankohtainen teema, jota teemanumero ei käsittele, liittyy sateenkaariperheiden eroihin, josta tutkimusta on toistaiseksi niukasti. Eron sosiaalisten seurausten näkökulmasta lapsen vanhempien sukupuolinen identiteetti tai seksuaalinen orientaatio on toissijaista, joten mitä pikemmin tutkimuksessa irtaudutaan yksioikoisesta heteronormatiivisuudesta sen parempi. Käsittelemättä jää myös väkivalta erojen ja parisuhdekonfliktien yhteydessä ja etnisyyteen ja kulttuuriseen moninaisuuteen liittyvät teemat. 
Tarvitsemme lisää empiiristä tutkimusta mutta myös teoreettisia jäsennyksiä ja käsitteitä, jotka auttavat ymmärtämään ja käsittelemään eroja laajakantoisena yhteiskunnallisena ilmiönä. Suomesta puuttuvat myös laajat tilastolliset aineistot, joilla eroon liittyviä ilmiöitä ja niiden yleisyyttä voisi tutkia tarkemmin. Erinomaisten väestörekisterien ansiosta eroamiseen liittyvä väestötieteellinen tutkimus on korkeatasoista, mutta se ei tartu yhteiskuntapoliittisiin ja sosiaalityön kannalta keskeisiin kysymyksiin. Niillä ei myöskään päästä helposti käsiksi esimerkiksi vähemmistöjen erojen erityispiirteisiin. Parisuhteiden muodostuminen ja päättyminen kytkeytyvät lukuisiin ajankohtaisiin kysymyksiin suomalaisessa yhteiskunnassa. Olisiko vihdoin aika laajamittaiseen tiedepoliittiseen panostukseen, jolla perheet ja niiden tulevaisuus nostettaisiin strategisesti tärkeiden tutkimusteemojen joukkoon?

Anna-Maija Castrén, Mia Hakovirta ja Marjo Kuronen 